\title{
COVID-19 Infection Risk Index Estimation in Flight Destinations (case study: Kish Air destinations)
}

\author{
I. Shafieenejad ${ }^{1 *}$, Sh.Ghasemi ${ }^{2}$, M. Siami ${ }^{3}$ \\ 1. Aerospace Research Institute, Ministry of Science, Research and Technology, Tehran, Iran
}

2. Polytechnic University of Madrid, Madrid, Spain

3. Department of Aerospace Engineering, Faculty of Engineering, Science and Research Branch, Islamic Azad university, Tehran, Iran

\begin{abstract}
This paper proposes a risk assessment method for estimating theCOVID-19 Infection risk index in flight destinations based on the pair wise comparison method to solve the problem of health monitoring devices shortage in airlines. In this research, Kish Airlines flight destinations are considered as a case study. By considering the importance of continuing air travel during COVID-19 pandemic, one of the most effective ways for decreasing the risk of infection to COVID-19 in air travel is establishing health monitoring stations at the airport gates. Because of the enormous number of airports and airline routes, nationwide coverage of them by the establishment of the health monitoring stations is unimaginable. Therefore, in this paper, the pair wise comparison method used for evaluating COVID-19 infection risk index in selected flight destinations and to evaluate the optimal policy for allocation of health monitoring equipment in Kish Airline destinations a geostatistical map is designed based on the calculated infection risk score.
\end{abstract}

Keyword: COVID-19; Infection Risk index; Risk assessment model; Pair wise comparison.

\section{Nomenclature and units*}

The Notation to be used in this paper listed as follows:

$\mathrm{M}_{\mathrm{ij}} \quad$ The probability parameter

superiority

n Systems step number

The probability of selected member winning in the comparison process

$\mathrm{x}$ The numerical value of the input parameter

$r \quad$ Statistical range

S Standard deviation

$\mathrm{x}_{\mathrm{S}} \quad$ The Normalized value of the input parameter

\section{Introduction}

The first Comprehensive report about corona virus (COVID-19) was released in December 2019 in Wuhan,

\footnotetext{
*.Corresponding Author Emails: shafieenejad@ari.ac.ir
}

Hubei Province, China [1]. Eight months after this report, more than 23 million people worldwide have been infected, and 800,000 have died from COVID-19 complications. Due to the absence of effective vaccines and medications to combat the virus, immediate actions should be taken to control the pandemic. In infectious diseases such as COVID-19, there are three approaches to control the outbreak. The first method is to blockade the virus in the infected Cities. In this method, populated places such as schools and public markets are closed, and stay-at-home orders establish by central governments[2]. In the second method, If the establishment of the restriction's rules cannot reduce the number of infected cases and the number of hospitalizations is accelerated, local authorities will impose the travel ban restriction between the cities and announcing the quarantine status[3, 4]. In the third stage, if the outbreak gets out of control, public health authorities will try to control the number of deaths by protecting vulnerable age groups against the disease[5]. Imposed the quarantine statutes is the hard decision for controlling the COVID-19outbreak. Shutting down public places and establishing stay-at-home orders can cause widespread social and economic problems in quarantined cities $[6,7]$. 
Transportation of goods and services by airlines is so important. During the travel ban order, health authorities impose restrictions to stop airlines flying from infected cities[8]. Due to the necessity of continuing flights during the COVID-19 pandemic, one of the proposed solutions to control the infection risk in air travel and prevent the spread of the virus by airlines is to equip the airport terminals with health monitoring devices such as COVID-19 rapid test kits and infrared camera for diagnosing the infected passengers. By considering the vastness of airports, full coverage of all flight routes is impossible due to the limited available number of health monitoring devices $[9,10]$. To address this issue we proposed a risk assessment model to find an optimal distribution policy of health monitoring devices based on the COVID-19 infection risk index in selected airport terminals. The COVID-19 infection risk index in this paper is calculated based on the pairwise comparison method. In this method, the infection risk index of the selected flight destination is estimated by scoring the parameters associated with COVID-19 infection risk. Moreover, we calculated a geostatistical map to discussed the optimal policy of allocation of health monitoring devices in selected flight destinations.

Coronavirus pandemic has radically changed the airline's business models. Due to the negative impact of the coronavirus pandemic on airlines many research articles have been published that offer different strategies for reducing the risk of infecting COVID-19 in air travel. In $[11,12]$ authors discussedCOVID-19 infection risk during the loading and boarding process in airport gates and suggest new methods to reduce the infection risk in airport terminals. According to researchers, despite the low chance of COVID19 transmission in air travel, most passengers have serious concerns about the safety of air travel during outbreaks. The studies suggest that by increasing the health safety protocols more passengers may decide to choose air travel during outbreaks[13-16].

In the following, the methodology of evaluation of the risk assessment model for estimating COVID-19 Infection Risk index is presented. The first part introduces the importance of studying the impact of the COVID-19 pandemic on airlines. In the second part, the COVID-19 pandemic impact on airline companies in 2020 is studied. In the third part of this research, the historical impact of past major outbreaks on airline industries is discussed. In the fourth section, the main reason for the selection of the parameters associated with the COVID-19 infection risk index was discussed. In the fifth section, the COVID-19infection risk score calculated based on the pair wise comparison methods and a geostatistical map generated. In this paper, kish airline, $\mathrm{s}$ flight destinations are considered as a case study. Furthermore, by evaluation of the risk assessment model the optimal policy for allocation of health monitoring equipment is discussed. Finally, a summary of pair wise comparison method application in modelling ofCOVID-19 risk index in kish airlines flight destinations is discussed.

\section{The impact of the COVID-19 virus on the general aviation industry}

The number of flights passenger has dropped dramatically since the World Health Organization declared the COVID-19 pandemic and international air travel bans had been imposed by local governments. The Impositions of international air travel bans have restricted the transfer of goods and services worldwide. In figure 1 the number of air travel in the united states of America compared for the same period in 2019 and $2020[17]$.

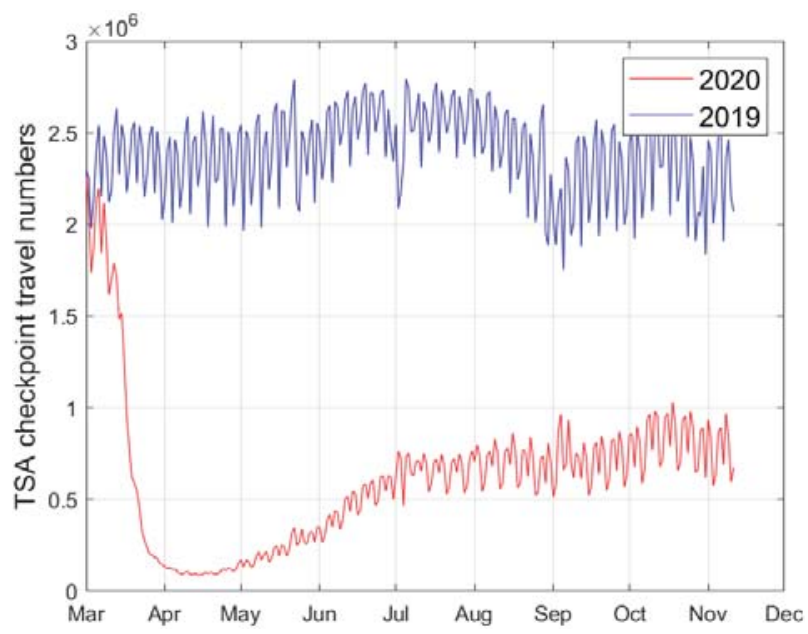

Figure 1. Travel numbers for 2020 and 2019 in the united states recorded by Transportation Security Administration

The main reasons for the reduction in the number of airline passengers are the imposition of quarantine restrictions by governments. According to the financial reviews during the first months of theCOVID-19 outbreak in 2020, the number of airline passengers decreased dramatically by about $40 \%$ globally, and the number of pre-sale tickets saw a $50 \%$ decreased in sale compared to the number of pre-sale tickets sold at the same period in 2019. [18, 19]. Similarly, due to the impact of the COVID-19 outbreak on the world economy World's GDP is expected to fall by 0.02 to 0.12 percent as the COVID-19 pandemic continues and the revenues in the aviation sector continue to decline significantly. This decline in World's GDP could lead to the loss of more than 25 to 35 million jobs in 2020 in the worst-case scenario [20]. In figure 2 the Corona virus impact on GDP growth factor for selected countries in the third quarter of 2020 has been shown[21, 22]. 


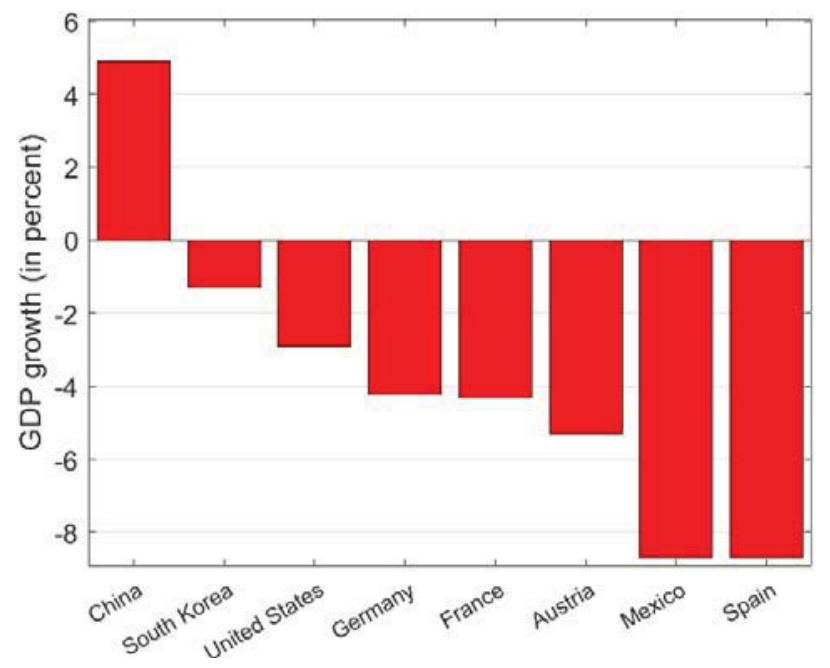

Figure 2. Coronavirus impact on GDP growth factor in selected countries for the third quarter of 2020

\section{The impacts of past outbreaks on the aviation industry}

Throughout the history of the aviation industry, global and local pandemics have raised economic doubts about airline companies. The first case of contagious disease impaction in the aviation industry saw in the late 1950s [23]. the outbreak of the flu virus Between 1957 and 1958, as well as between 1968 and 1970 has killed more than one million people, had been faced airlines with a new challenge for continuing their normal flight schedule while fewer passengers intended to choose airlines for traveling [24]. However, due to the limited number of passenger flights in the mentioned historical periods, the airlines were not widely faced with the challenge of reducing the number of their flights. But by studying the public response to the outbreak of contagious diseases airline companies try to find an effective strategy for managing financial crises during public pandemics.

In 2003, a widespread outbreak of severe acute respiratory syndrome (SARS) in the Far East led to widespread economic damage to airlines. Although about 8098 cases infected to the virus and less than 800 deaths have been recorded as a result of the SARS pandemic[25], due to the dramatic growth of the aviation industry in compared to the flu outbreak of the 1950 s, public fear and anxiety over the spread the disease had a profound effect on the decline in airline revenues in 2003. According to surveys conducted in 8 different regions of the world, more than $75 \%$ of the participants stated that they do not intend to use public transportation services during outbreaks[16]. According to the provided statistics, airlines based in the North American region have suffered a loss of one billion dollars as a result of the SARS pandemic and the decrease in the number of passengers [26].
Middle East Respiratory Syndrome (MERS) pandemic in 2012 in the Arabian Peninsula had less of an impact on airlines than the SARS outbreak. Based on previous experiences with past contiguous diseases, the Centers for Disease Control and Prevention (CDC) in the United States has set up health monitoring stations to closely monitor passengers on flights from the Arabian Peninsula to united states based airports [27].

The Ebola outbreak in West Africa in 2014 has been the next challenge for airlines facing financial crises. In response to the Ebola outbreak, a large number of non-African airlines, such as British Airways, have suspended their services in areas affected by the disease, and other airlines, such as Air France and the Dubai Emirates reduced their weekly flight numbers to the infected destinations [28]. To prevent the spread of the disease, European countries have legislated travel bans from the impacted areas, and in the North American region, all travelers with a history of traveling to outbreaks underwent medical examinations upon arrival. At airports located in outbreaks, all passengers are tested at arrival at health monitoring stations, and training brochures on how to properly deal with the virus are distributed among passengers[29, 30].

\section{The procedure of selecting the parameters associated with the COVID-19 infection risk index}

The selected parameter for model COVID-19 risk assessment in this paper includes Population, Population ages 50 and above, COVID-19 growth rates, COVID-19 infected cases, and the Total number of incoming and outgoing flights.

The population factor describes the number of people in selected destinations who can be infected with the COVID-19 virus and potentially transmit the virus to other cities. The new studies discussed that the populated cities catalyse the spread of COVID-19[3135].

The Population of people aged 50 and more may treat incoming passengers indirectly. In most case scenarios elderly people who are infected with COVID19 will need to be hospitalized for receiving specials aids[36] thus by considering the important role of the healthcare worker in hospital in taking care of elderly people the number of health care workers who could work in airports gate for diagnosing passengers may reduce considerably in cities with a high portion of elderly people.

COVID-19 growth rates and COVID-19 infected casesare two main factors that describe COVID-19 infection riskin flight destinations. By considering these two parameters the risk assessment model can predict the infection risk in a short period timebecause this number change radically every day the risk prediction model cannot rely on them for long time risk assessment. The total number of incoming and outgoing 
flights in airports describes airport congestion. Contagious disease like COVID-19 can easily transmit in populated places like airport terminals therefore by considering this parameter the chance of infecting COVID-19 in airport terminal will be conceded in the designed model.[37].

Finally, the number of Active bed per capita to the population by province factor describes the public health facilities of destination cities in treating people who infected to COVID-19. In cities with low health facilitiesfewer people will diagnose with test kit thus the chance of infecting to COVID-19 is much higher [38, 39]

\section{COVID-19 risk assessment model designation based on the pair wise comparison method}

Classification of statistical variables based on the degree of importance is one of the most complicated issues in statistical modelling problems. Deciding to determine the importance of each parameter is a time-consuming process when the relationship between the variables of each parameter is unclear to each other [40]. There are several decision-making methods based on data type, variables dependency, and the amount of information provided for each variable that has been developed and presented. Decision methods for classifying variables based on variable structure include deterministic methods, stochastic classification, and Multiple-criteria decision-making method.

The pair wise comparison method is the simpler form of the analytic hierarchy process (AHP). The AHP usually use for choosing the best decision among available options, as long as the only discussed decision in this paper is to scoring the relevant factors to the infection risk index, we decide to use the pairwise comparison method to reduce the complexity of the parameter scoring process. The pairwise comparison method is based on the multiple-criteria decisionmaking method which can rank and scoring the members of a specific category [41].

In the pairwise comparison method, the studied parameters such as (population, percentage of the population over 50 years, the growth rate of COVID-19 virus, etc.) are measured in pairs relative to each other, while the $\alpha$ member with the probability of $M_{i j}=(0,1)$ is superior to the $\beta$ member. The importance of each parameter compared to the other is determined and scored based on Table 1 [42]. The output of the pairwise comparison method is statistically considered a random and non-independent variable. The classification of members is defined by Equation (1) based on the unpredictable score of $\tau_{i}$ which is the probability of member $\alpha$ winning over the selected comparable member $\beta$ with the step number of $n$.

$$
\tau_{i}:=\frac{1}{\mathrm{n}-1} \sum_{\mathrm{j} \neq 1} \mathrm{M}_{\mathrm{ij}} .
$$

Table 1. Definition of descriptive and numerical scores in the pair wise comparison method

\begin{tabular}{|c|c|}
\hline Descriptive score & Numerical score \\
\hline Not preferred & 0 \\
\hline Somewhat preferred & 0.25 \\
\hline Equally preferred & 0.5 \\
\hline Highly preferred & 0.75 \\
\hline Absolutely preferred & 1 \\
\hline
\end{tabular}

To determine the contribution of each parameter we compare the degree of importance of each parameter based on Table 1criteria and Equation 1. The figure 3 show that how every two parameters compare mutually based on 24 judgmental connections that established for calculating the final degree of importance score for selected parameters. The scored parameters showed in Table 2 .

Table 2. Scoring parameters related to COVID-19 Infection Risk Index

\begin{tabular}{|c||c|c|c|c|c|c|}
\hline & Population & $\begin{array}{c}\text { Population } \\
\text { ages 50 and } \\
\text { above }\end{array}$ & $\begin{array}{c}\text { COVID-19 } \\
\text { growth } \\
\text { rate }\end{array}$ & $\begin{array}{c}\text { COVID-19 } \\
\text { infected } \\
\text { cases }\end{array}$ & $\begin{array}{c}\text { Active bed per } \\
\text { capita to population } \\
\text { by province }\end{array}$ & $\begin{array}{c}\text { Total number } \\
\text { of incoming } \\
\text { and outgoing } \\
\text { flights }\end{array}$ \\
\hline \hline \begin{tabular}{c} 
Population \\
\hline \multirow{2}{*}{$\begin{array}{c}\text { Population ages 50 and } \\
\text { above }\end{array}$}
\end{tabular} & $-\mathbf{0 . 7 5}$ & - & $\mathbf{0 . 5}$ & 0.25 & 0.25 & 0.5 \\
score \\
\hline $\begin{array}{c}\text { Total } \\
\text { COVID-19 growth rate }\end{array}$ & $\mathbf{0 . 5}$ & $\mathbf{0 . 2 5}$ & $\mathbf{0 . 7 5}$ & 1 & 0.5 & 0 \\
\hline
\end{tabular}




\begin{tabular}{|c||c|c|c|c|c|}
\hline COVID-19 infected cases & $\mathbf{0 . 7 5}$ & $\mathbf{0}$ & $\mathbf{0 . 5}$ & 0.5 \\
\hline $\begin{array}{c}\text { Active bed per capita to } \\
\text { population by province }\end{array}$ & $\mathbf{0 . 7 5}$ & $\mathbf{0 . 5}$ & $\mathbf{0 . 7 5}$ & 0.5 \\
\hline $\begin{array}{c}\text { Total number of incoming } \\
\text { and outgoing flights }\end{array}$ & $\mathbf{0 . 5}$ & $\mathbf{1}$ & $\mathbf{0 . 5}$ & 0.5 \\
\hline
\end{tabular}

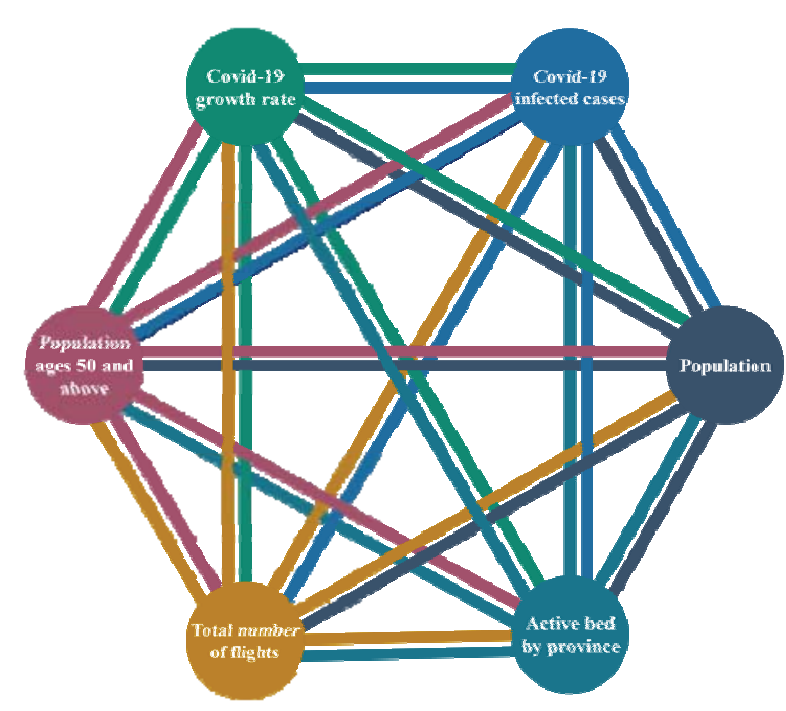

Figure 3. The mutual relation of related factors to infection risk index in pair wise comparison method scoring system

In Table 3 the statistical data of parameters that are related to COVID-19 infection risk is determined for

Table 3. Parameters related to COVID-19 Infection Risk Index based on flight destinations of Kish Airlines

\begin{tabular}{|c|c|c|c|c|c|c|}
\hline Cities & Population & $\begin{array}{l}\text { Population ages } \\
50 \text { and above }\end{array}$ & $\begin{array}{l}\text { COVID-19growth } \\
\text { rates }\end{array}$ & $\begin{array}{l}\text { COVID-19 infected } \\
\text { cases }\end{array}$ & $\begin{array}{l}\text { Active bed per } \\
\text { capita to } \\
\text { population by } \\
\text { province }\end{array}$ & $\begin{array}{l}\text { Total number of } \\
\text { incoming and } \\
\text { outgoing flights }\end{array}$ \\
\hline Tehran & 8693706 & 19.3 & 169.93 & 5098 & 2.08 & 26 \\
\hline Mashhad & 3001184 & 15.9 & 19.5 & 858 & 1.5 & 12 \\
\hline Isfahan & 1961260 & 19.5 & 65.96 & 1979 & 1.56 & 14 \\
\hline Shiraz & 1565572 & 17.6 & 16.83 & 505 & 1.8 & 8 \\
\hline Yazd & 529673 & 16.1 & 24.16 & 725 & 2.48 & 4 \\
\hline $\begin{array}{l}\text { Bandar } \\
\text { Abbas }\end{array}$ & 526648 & 11.8 & 4.93 & 148 & 1.23 & 12 \\
\hline Abadan & 231476 & 13.8 & 14.8 & 444 & 1.56 & 6 \\
\hline
\end{tabular}

Kish airlines domestic flight destinations[43-46]. Selected flight destinations include Tehran, Mashhad, Isfahan, Shiraz, Yazd, Kish, Asaluyeh, Abadan, and Bandar Abbas.

Statistical data related to the variables classified in Table 3 are dispersed in compared to each other, which makes it difficult to statistically model the risk index of COVID-19 in the cities under study. Statistical parameters are comparable to each other if they are normalized to a specific parameter or population. Accordingly, performing data normalization operations on a specific variable causes the statistical data provided for different groups to be measured relative to each other. This is possible by transferring the data to the Zscore format [47]. In the Z-score normalization method, statistical data are normalized based on the difference of each data from the standard deviation and based on the numerical range from 0 to 1 . 


\begin{tabular}{|c|c|c|c|c|c|c|}
\hline Asaluyeh & 73958 & 12.9 & 1.83 & 55 & 1.22 & 4 \\
\hline Kish & 39853 & 11.8 & 4.93 & 148 & 1.23 & 40 \\
\hline
\end{tabular}

For weighting, statistical data of Table 3 based on the total scores categorized in Table 2, statistical data based on Equation (2) are normalized in the numerical ranges 0 and 1 .

$$
x_{s}=\frac{x-r}{s}
$$

In this equation, $x$ is the numerical value of the input, and the parameters $r$ and $s$ represent the statistical range and standard deviation and $\mathrm{x}_{\mathrm{S}}$ is the normalized value of the input parameter.

After normalizing the statistical data from table 3 the calculated scores multiply in each statistical data subject. By multiplying the score in each parameter, the degree of importance of each parameter is calculated for each city. Finally, by summation of weighted statistical data for each destination the raw COVID-19 infection score is calculated for flight destinations Table 4.

Table 4. Normal and weighted statistical parameters related to COVID-19 Infection Risk Index

\begin{tabular}{|c|c|c|c|c|c|c|}
\hline Cities & Population & $\begin{array}{l}\text { Population ages } \\
50 \text { and above }\end{array}$ & $\begin{array}{l}\text { COVID-19growth } \\
\text { rates }\end{array}$ & $\begin{array}{c}\text { COVID-19 } \\
\text { infected cases }\end{array}$ & $\begin{array}{l}\text { Active bed per } \\
\text { capita to } \\
\text { population by } \\
\text { province }\end{array}$ & $\begin{array}{l}\text { Total number of } \\
\text { incoming and } \\
\text { outgoing flights }\end{array}$ \\
\hline Tehran & 8693706 & 19.3 & 169.93 & ב5098 & 2.08 & 26 \\
\hline Mashhad & 3001184 & 15.9 & 19.5 & 858 & 1.5 & 12 \\
\hline Isfahan & 1961260 & 19.5 & 65.96 & 1979 & 1.56 & 14 \\
\hline Shiraz & 1565572 & 17.6 & 16.83 & 505 & 1.8 & 8 \\
\hline Yazd & 529673 & 16.1 & 24.16 & 725 & 2.48 & 4 \\
\hline $\begin{array}{l}\text { Bandar } \\
\text { Abbas }\end{array}$ & 526648 & 11.8 & 4.93 & 148 & 1.23 & 12 \\
\hline Abadan & 231476 & 13.8 & 14.8 & 444 & 1.56 & 6 \\
\hline Asaluyeh & 73958 & 12.9 & 1.83 & 55 & 1.22 & 4 \\
\hline Kish & 39853 & 11.8 & 4.93 & 148 & 1.23 & 40 \\
\hline
\end{tabular}

According to Table 4, during the peak period of the COVID-19 virus pandemic in February 2020 in Iran [48], Tehran province has the highest , and Asaluyeh city has the lowest risk of virus infection. The risk index of COVID-19 normalized in the numerical range from 0 to10 is shown in figure 4 .

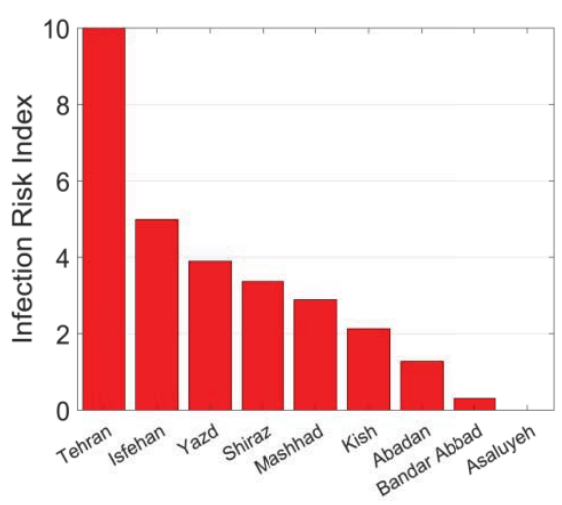

Figure 4. Normalized risk index of COVID-19 in kish airlines flight destinations
The COVID-19 risk assessment model designed based on categorized the selected flight destinations in three risk groups namely: red, orange, and yellow in terms of COVID-19 virus infection risk index in a geostatistical map figure 5.By considering COVID-19 infection risk in red and orange cities, allocation of forces and health monitoring equipment at those airports should be considered.

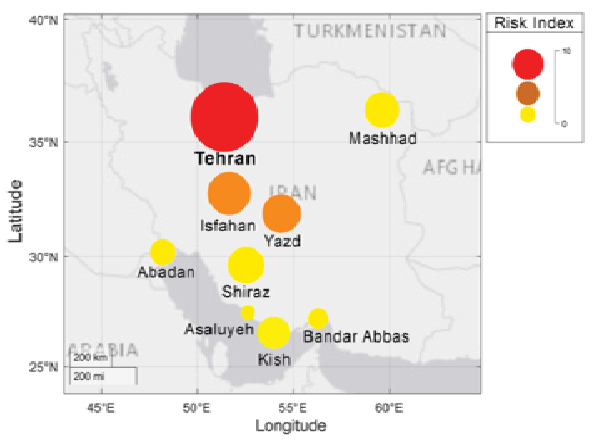

Figure 5. Geostatistical map of COVID-19 infection risk index in Kish airlines flight destinations 


\section{Conclusions}

In this paper, the COVID-19 risk index in kish airlines' weekly flight destinations was estimated by the risk assessment model that was designed based on the pairwise comparison method. Due to the number of airports and airline routes and the lack of health monitoring equipment, by determining the risk index of the COVID-19 virus for the weekly flight routes of Kish Airlines, the optimal policy for distribution of health monitoring equipment is determined. According to the results, Kish Airlines' weekly flight destinations are presented in three categories of red, orange, and yellow in terms of the COVID-19 virus infection risk score. Accordingly, the risk of passengers and flight crew infection to the COVID-19 virus is high at the destinations in the red and orange categories. Due to the high risk of passengers getting COVID-19 virus in cities of origin in the red and orange categories, the allocation of forces and health monitoring equipment at those airports should be considered. giving passengers and flight crews the right information about how to protect themselves at the time of COVID-19 outbreak can increase the safety and reliability of flight travels.

\section{References}

[1] Yang X, Yu Y, Xu J, Shu H, Xia J, Liu H, et al. Clinical course and outcomes of critically ill patients with SARS-CoV-2 pneumonia in Wuhan, China: a single-centered, retrospective, observational study. Lancet Respir Med. 8(5): 475-481 (2020).

[2] Hale T, Angrist N, Cameron-Blake E, Hallas L, Kira B, Majumdar $\mathrm{S}$, et al. Variation in government responses to COVID-19. BSG Work Pap Ser Blavatnik Sch Gov Univ Oxford. 31: Version 8.0 (2020).

[3] Hou C, Chen J, Zhou Y, Hua L, Yuan J, He S, et al. The effectiveness of quarantine of Wuhan city against the Corona Virus Disease 2019 (COVID-19): A wellmixed SEIR model analysis. J Med Virol. 92(7): 841848 (2020).

[4] Rodríguez-Urrego D, Rodríguez-Urrego L. Air quality during the COVID-19: PM2.5 analysis in the 50 most polluted capital cities in the world, (2020).

[5] Jordan RE, Adab P, Cheng KK. COVID-19: Risk factors for severe disease and death, (2020).

[6] Casagrande M, Favieri F, Tambelli R, Forte G. The enemy who sealed the world: effects quarantine due to the COVID-19 on sleep quality, anxiety, and psychological distress in the Italian population. Sleep Med. 75: 12-20 (2020).

[7] Ashraf BN. Economic impact of government interventions during the COVID-19 pandemic: International evidence from financial markets. J Behav Exp Financ. 27: 100371 (2020).

[8] Chinazzi M, Davis JT, Ajelli M, Gioannini C, Litvinova M, Merler S, et al. The effect of travel restrictions on the spread of the 2019 novel coronavirus
(COVID-19) outbreak. Science (80- ). 368(6489): 395400 (2020).

[9] Ranney ML, Griffeth V, Jha AK. Critical Supply Shortages - The Need for Ventilators and Personal Protective Equipment during the COVID-19 Pandemic. N Engl J Med. 382(18): e41 (2020).

[10] Beetz C, Skrahina V, Forster TM, Gaber H, Paul JJ, Curado F, et al. Rapid large-scale COVID-19 testing during shortages. Diagnostics. 10(7): 464 (2020).

[11] Cotfas LA, Delcea C, Milne RJ, Salari M. Evaluating classical airplane boarding methods considering COVID-19 flying restrictions. Symmetry (Basel). 12(7): 1087 (2020).

[12] John Milne R, Delcea C, Cotfas L-A. Airplane Boarding Methods that Reduce Risk from COVID-19. Saf Sci. 105061 (2020).

[13] Bielecki M, Patel D, Hinkelbein J, Komorowski M, Kester J, Ebrahim S, et al. Air travel and COVID-19 prevention in the pandemic and peri-pandemic period: A narrative review. Travel Med Infect Dis. 39: 101915 (2021).

[14] Berry LL, Danaher TS, Aksoy L, Keiningham TL. Service Safety in the Pandemic Age. J Serv Res. 23(4): 391-395 (2020).

[15] Neuburger L, Egger R. Travel risk perception and travel behaviour during the COVID-19 pandemic 2020: a case study of the DACH region. Curr Issues Tour. 114 (2020).

[16] Sadique MZ, Edmunds WJ, Smith RD, Meerding WJ, De Zwart O, Brug J, et al. Precautionary behavior in response to perceived threat of pandemic influenza. Emerg Infect Dis. 13(9): 1307-1313 (2007).

[17] TSA. TSA checkpoint travel numbers for 2020 and 2019, Available from: https://www.tsa.gov/coronavirus/passenger-throughput.

[18] Airports Council International Advisory Bulletin: The Impact of COVID- 19 on the Airport Business. Montreal, Canada: Airports Council International. (2020).

[19] Air Transport Bureau. Effects of Novel Coronavirus (COVID-19) on Civil Aviation: Economic Impact Analysis. Int Civ Aviat Organ (ICAO), Montréal, Canada. (March): 4 (2020).

[20] Iacus SM, Natale F, Satamaria C, Spyratos S, Vespe M. Estimating and projecting air passenger traffic during the COVID-19 coronavirus outbreak and its socioeconomic impact, (2020).

[21] OECD. OECD Economic Outlook, Volume 2020 Issue 2: Preliminary version, No. 108. (2020).

[22] Quarterly Growth Rates of real GDP, change over previous quarter, Available from: https://stats.oecd.org/index.aspx?queryid=350.

[23] Henderson DA, Courtney B, Inglesby T V., Toner E, Nuzzo JB. Public health and medical responses to the 1957-58 influenza pandemic. Biosecurity and Bioterrorism. 7(3): 265-273 (2009).

[24] Kilbourne ED. Influenza pandemics of the 20th century, (2006). 
[25] Chan-yeung $\mathrm{M}, \mathrm{Xu}$ R. SARS : epidemiology CUMULATIVE NUMBER OF CASES AND DEATHS IN VARIOUS COUNTRIES IN. Respirology. 8: S9-S14 (2003).

[26] Robertson CT. Vaccines and airline travel: A federal role to protect the public health. Am J Law Med. 42(23): 543-571 (2016).

[27] Williams HA, Dunville RL, Gerber SI, Erdman DD, Pesik N, Kuhar D, et al. CDC's Early Response to a Novel Viral Disease, Middle East Respiratory Syndrome Coronavirus (MERS-CoV), September 2012-May 2014. Public Health Rep. 130(4): 307-317 (2015).

[28] Amankwah-Amoah J. Ebola and Global Airline Business: An Integrated Framework of Companies' Responses to Adverse Environmental Shock. Thunderbird Int Bus Rev. 58(5): 385-397 (2016).

[29] Cohen NJ, Brown CM, Alvarado-Ramy F, Bair-Brake $\mathrm{H}$, Benenson GA, Chen TH, et al. Travel and Border Health Measures to Prevent the International Spread of Ebola. MMWR Suppl. 65(3): 57-67 (2016).

[30] Read JM, Diggle PJ, Chirombo J, Solomon T, Baylis M. Effectiveness of screening for Ebola at airports, (2015).

[31] Rocklöv J, Sjödin H. High population densities catalyse the spread of COVID-19. J Travel Med. 27(3): 1-2 (2020).

[32] Ribeiro H V., Sunahara AS, Sutton J, Perc M, Hanley QS. City size and the spreading of COVID-19 in Brazil. PLoS One. 15(9 September 2020): e0239699e0239699 (2020).

[33] Stier AJ, Berman MG, Bettencourt LMA. COVID-19 attack rate increases with city size. 1-23 (2020).

[34] Coelho MTP, Rodrigues JFM, Medina AM, Scalco P, Terribile LC, Vilela B, et al. Global expansion of COVID-19 pandemic is driven by population size and airport connections. PeerJ. 8: 1-14 (2020).

[35] Coşkun H, Yıldırım N, Gündüz S. The spread of COVID-19 virus through population density and wind in Turkey cities. Sci Total Environ. 751: 141663 (2021).
[36] Daoust JF. Elderly people and responses to COVID-19 in 27 Countries. PLoS One. 15(7): e0235590 (2020).

[37] Roy S, Ghosh P. Factors affecting COVID-19 infected and death rates inform lockdown-related policymaking. PLoS One. 15(10): e0241165 (2020).

[38] Murray CJ. Forecasting COVID-19 impact on hospital bed-days, ICU-days, ventilator-days and deaths by US state in the next 4 months. 114 (2020).

[39] Ferstad J, Gu A, Lee R, Thapa I, Shin A, Salomon J, et al. A model to forecast regional demand for COVID-19 related hospital beds. (2020).

[40] Yeh CH, Deng H, Pan H. Multi-criteria analysis for dredger dispatching under uncertainty. J Oper Res Soc. 50(1): 35-43 (1999).

[41] Wauthier FL, Jordan MI, Jojic N. Efficient ranking from pairwise comparisons. In 30th International Conference on Machine Learning, ICML 2013 pp. 1146-1154 (2013).

[42] Schnepp GJ, Arrow KJ. Social Choice and Individual Values. Am Cathol Sociol Rev. 12(4): 243 (1951).

[43] Hospital statistics and information, Ministry of Health and Medical Education, Available from: http://td.lums.ac.ir/parameters/lums/modules/cdk/uploa d/content/portal_content/File/darman/madarek pezeshki/avab.pdf.

[44] Statistical Centre of Iran, Available from: https://www.amar.org.ir/english.

[45] COVID-19 National Geoportal, Available from: https://iransdi.ir/layersf/Corona\#.

[46] Kish Airlines Flight Schedule \& Timetable, Available from: https://www.kishairlines.ir/flight-destinations/.

[47] Jain A, Nandakumar K, Ross A. Score normalization in multimodal biometric systems. Pattern Recognit. 38(12): 2270-2285 (2005).

[48] Aghaali M, Kolifarhood G, Nikbakht R, Saadati HM, Hashemi Nazari SS. Estimation of the serial interval and basic reproduction number of COVID-19 in Qom, Iran, and three other countries: A data-driven analysis in the early phase of the outbreak. Transbound Emerg Dis.

(2020). 